\title{
Anti-Obesity Effect of Fructus Pyri Pyrifoliae Extract Fermented by Lactic-Acid Bacteria on Rats
}

*Correspondence to:

Kim J,

(iD http://orcid.org/0000-0003-3984-6049

Tel: $+82-61-330-3512$

Fax: +82-61-330-3519

E-mail: jskim@dsu.ac.kr

Received August 22, 2018

Revised September 19, 2018

Accepted September 20, 2018

\author{
Hanna Chu, Jeongsang Kim* \\ College of Korean Medicine, Dongshin University, Naju 58245, Korea
}

\begin{abstract}
This study investigated the anti-obesity effect of a pear (Fructus Pyri Pyrifoliae) extract fermented by lactic-acid bacteria on obesity induced by a high-fat diet in rats. Body-weight measurement, blood analysis, and light microscope observation of adipose tissue in liver and epididymis were conducted after 8 weeks. Gene expression of leptin, adiponectin, and tumor necrosis factor- $\alpha$ (TNF- $\alpha$ ) in liver cells were also investigated. Compared to CON, PFA and PFB showed 8\% weight reduction along with weight reduction of adipose tissue in liver and epididymis. Observing the microstructure of liver cells showed that lipid droplets were smaller in PFA and PFB than in CON. We confirmed that Fructus Pyri Pyrifoliae extract fermented by lactic-acid bacteria can affect gene expression of leptin, adiponectin, and TNF- $\alpha$ in liver cells, showing an obesity treatment effect. From the results above, it was observed that weight gain from increased gene expression in adipose cells as well as from the increased proportion of adipose cells caused by a high-fat diet can be statistically significantly reduced by taking Fructus Pyri Pyrifoliae extract fermented by lactic-acid bacteria. Therefore, Fructus Pyri Pyrifoliae extract fermented by lacticacid bacteria can be effective for preventing and treating obesity by reducing weight and adipose cells.
\end{abstract}

Key Words: Fructus Pyri Pyrifoliae, Anti-obesity, Lactic-acid bacteria, Adipose cell

\section{INTRODUCTION}

Obesity occurs when adipose cells are actively differentiated and triglyceride is excessively accumulated because of excess energy intake (Bae et al., 2014). Obesity can increase the risk of lifestyle diseases such as hypertension, arteriosclerosis, cardiovascular disease, and diabetes. The obesity rate is increasing remarkably in the world, including South Korea, and there is much research on how to reduce obesity in the population (Jequier, 2002; Wang \& Cho, 2011).

Fructus Pyri Pyrifoliae contains components such as arbutin, catechin, and epicatechin, which are phenols, as well as amino acids, organic acids, dietary fiber, and flavonoids (Rhyu et al., 2014). These components are known to help prevent prostate cancer, cardiovascular disease, osteoporosis, postmenopausal symptoms, hormone-dependent diseases, and obesity (Tsai et al., 2009). Fructus Pyri Pyrifoliae is composed of skin (exo- carp), pulp (mesocarp), and core (endocarp), and, according to a recent study, there are 2 to 9 times more phenols in the skin than in the pulp (Park \& Han, 2015); hence this fruit might provide valuable products if more of it is used, not just its pulp or extract.

As one food-processing method, fermented drinks are a traditional product that provides lactic-acid bacteria to humans. Especially, fruits and vegetables have been considered ideal sources for developing non-diary drinks. Fruits, which generally contain vitamins, anti-oxidants, and polyphenols, offer numerous benefits for growth and survival of probiotic microorganisms. Therefore, many studies are trying to develop fermented foods by using fruits (Maria \& Athanasios, 2016). Specifically, lactic-acid bacteria have been used as seed bacteria in many foods, and play an important role in human or animal intestines. Lactic-acid bacteria have an anti-oxidation effect that protects against reactive oxygen species (Kim \&

(a) This is an open-access article distributed under the terms of the Creative Commons Attribution Non-Commercial License (http://creativecommons.org/licenses/by-nc/4.0) which permits unrestricted noncommercial use, distribution, and reproduction in any medium, provided the original work is properly cited.

Copyrights @ 2018 by Korean Society of Microscopy 
Ham, 2003). Lactic-acid bacterial fermentation is one of the most notable research topics all over the world, including South Korea, using Kimchi, fruits, vegetable, tea, and medicinal herbs as well as dairy products. Lactic-acid bacterial fermentation is being studied to improve it and diversify its use. Yang et al. (2014) confirmed that mushroom water extract fermented by lactic-acid bacteria can increase mushroom's high anti-oxidative activity, and Kim et al. (2016) verified that Houttuynia cordata Thunb fermented by lactic-acid bacteria has better antioxidative activity than non-fermented Houttuynia cordata Thunb. Like these, there have been many studies of lactic-acid bacteria fermentation.

In this study, we aim to suggest that Fructus Pyri Pyrifoliae extract fermented by Leuconostoc mesenteroides could be a functional food by feeding Fructus Pyri Pyrifoliae extract fermented by lactic-acid bacteria to rats, in order to confirming that it inhibits fat accumulation.

\section{MATERIALS AND METHODS}

\section{Experimental Animals}

Six-week-old male Sprague-Dawley rats, weighing around $180 \mathrm{~g}$, were purchased and housed for 2 weeks before being tested in the animals breeding room of the College of Oriental Medicine, Dongshin University. They were maintained in a controlled light cycle (12-hour light and 12-hour dark), temperature $\left(21^{\circ} \mathrm{C} \pm 2^{\circ} \mathrm{C}\right)$, illumination intensity (150 300 Lux), and humidity (50\% 60\%). During this experiment, enough normal solid feed (NOR), 60\% high-fat feeds, and water were provided to the rats. All experiments were conducted after Institutional Review Board approval by the Institutional Animal Care and Use Committees of Dongshin University (approval no. 2014-05-03-02).

\section{Manufacturing Fructus Pyri Pyrifoliae Extract Fermented by Lactic-Acid Bacteria}

Fructus Pyri Pyrifoliae extract fermented by lactic-acid bacteria was manufactured by cultivating L. mesenteroides subsp. mesenteroids in MRS broth (Becton, Dickinson and Company, USA and Germany) at $30^{\circ} \mathrm{C}$ for 72 hours. After extraction of Fructus Pyri Pyrifoliae, its sludge was separately isolated. The sludge of Fructus Pyri Pyrifoliae and purified water were mixed in the ratio $8: 2$, stirred, and sterilized at $70^{\circ} \mathrm{C}$ for one hour. The culture medium of lactic-acid bacteria was inoculated into the sterilized sludge of Fructus Pyri Pyrifoliae so that the culture medium accounted for $5 \%$ of total volume. The Fructus Pyri Pyrifoliae sludge and lactic-acid bacteria were cultivated at $30^{\circ} \mathrm{C}$ for 24 hours, and were then filtered.

\section{Administration of Substance}

Fructus Pyri Pyrifoliae extract fermented by lactic-acid bacteria blended with water was given to experimental groups for
8 weeks. During the 8 weeks of the experimental period, the laboratory rats were divided into 4 groups, each consisting of 6 rats: a normal-diet group fed on NOR; a control group fed on a $60 \%$ high-fat diet (HFD) (CON); a group fed a $60 \%$ HFD and $1.7 \mathrm{~mL} / \mathrm{kg} /$ day Fructus Pyri Pyrifoliae extract fermented by lactic-acid bacteria (PFA); and a group fed a $60 \%$ HFD and $5 \mathrm{~mL} / \mathrm{kg} /$ day Fructus Pyri Pyrifoliae extract fermented by lactic-acid bacteria (PFB).

\section{Body Weight Measurement}

Body weight (unit: g) was measured once a week during the experiment using a digital scale (TS4KK; OHAUS Corporation, USA).

\section{Blood Analysis}

After each administration, all the rats were fasted for 12 hours. Then, they were anesthetized with Urethane $(75 \mathrm{mg} / \mathrm{kg})$, their blood samples were collected, and the blood samples were put into EDTA bottles. White blood cell (WBC), red blood cell (RBC), hemoglobin, hematocrit, and platelet levels were immediately measured by using a hematology analyzer (HEMAVET 950 FS; Drew-Scientific, USA). For measuring the serum level of total cholesterol, triglyceride, and high density lipoprotein cholesterol (HDL-C), serum collected from each rat was transferred into a serum bottle at room temperature, centrifuged for 15 minutes at 3,000 rpm by using a centrifuge (VS6000CFi; VISIONBIONEX, Korea). Then, supernatants were taken, deposited on serum analysis slides (Fujiflim Corporation, Japan), and analyzed by a biochemical analyzer (Fujiflim Corporation).

\section{Weight Measurement of Liver and Epididymis}

Liver and epididymis were harvested from rats and washed out by phosphate buffered saline. Then, each tissue weight was measured by a balance (WB0710037; KERN \& Sohn $\mathrm{GmbH}$, Germany). For the liver, the whole organ was harvested, whereas only the left side of epididymis adipose tissue was harvested.

\section{Light Microscope Observation of Adipose Tissue of Liver and Epididymis}

For observation of adipose tissue of liver and epididymis, rats were sacrificed and the corresponding tissues were removed. The harvested tissues were fixed with $10 \%$ formalin for 48 hours, and transferred sequentially to $30 \%, 50 \%, 70 \%, 80 \%$, $90 \%, 95 \%, 100 \%$ I, and $100 \%$ II alcohols for dehydration. After that, the tissues were cleared with xylene and embedded in paraffin. The paraffin-embedded tissues were cut into $5-\mu \mathrm{m}$ thick slices by a microtome. The $5 \mu \mathrm{m}$ slices were placed on glass slides, paraffin was removed by xylene, and they were hydrated by a graded ethanol dilution series of $100 \%, 90 \%$, and $80 \%$. The slices were stained by hematoxylin and eosin, dehy- 
drated, and mounted by canada balsam. By a camera attached to the light microscope (Nikon Eclipse 80i; Nikon, Japan), the slices were examined, and photo images were taken.

\section{Measurement of Adipose Cell Size in Epididymis}

To measure the size of adipose cells in epididymis, a microscope with reticle lens (M309237; Zeiss, Germany) was used and the cell size was measured using the low-power objective $(\times 100)$ lens. For each group, the measurements were carried out 15 times, and the mean of 15 measurements for each group was considered to the adipose cell size of the corresponding group.

\section{Electron Microscope Observation}

For observing the structure of liver tissue cells using an electron microscope, the liver tissues were harvested, cut into 1 $\mathrm{mm}^{3}$ size, and fixed with $2.5 \%$ glutaraldehyde for 2 hours. The tissues were dehydrated by a graded alcohol series of $50 \%$, $70 \%, 85 \%, 90 \%, 95 \%$, and $100 \%$, substituted with propylene oxide, and embedded with epon mixture. The epon mixtureembedded tissues were cut into microsection using microsectioning equipment (705001; Leica Mikrosysteme GmbH, Austria), and double stained with uranyl acetate and lead citrate. The prepared samples were observed by using a transmission electron microscope (JEM 100 CX-II; JEOL, Japan).

\section{RNA Isolation in Liver Tissue}

RNA in liver tissue was isolated. At the last week of the experiment, rats were sacrificed. Following opening of the abdomen, the liver tissue was immediately isolated, $0.1 \mathrm{~g}$ of the isolated tissue of each group was transferred into a tube, $1 \mathrm{~mL}$ total RNA isolation-solution was added, and each tissue in the tube was homogenized. The homogenized tissue was transferred to another tube, isopropanol was added, and the tissue was left for 5 minutes. Following centrifugation, all the solution except the pellet was discarded. After washing out with ethanol, RNA was obtained.

\section{Gene Expression of Leptin, Adiponectin, and Tumor Necrosis Factor- $\alpha$ (TNF- $\alpha$ ) in Liver Cells}

Gene expression of leptin, adiponectin, and TNF- $\alpha$ in liver cells was measured by using reverse transcription-polymerase chain reaction (PCR). RT Premix (K-2044 CycleScript RT PreMix [dT20]; Bioneer, USA) was added to the isolated RNA, and the reaction proceeded at $95^{\circ} \mathrm{C}$ for 60 minutes, followed by $95^{\circ} \mathrm{C}$ for 5 minutes and $4^{\circ} \mathrm{C}$ for 5 minutes. After carrying out cDNA synthesis, PCR Premix (K-2016; Bioneer) was mixed with primers for leptin, adiponectin, TNF- $\alpha$, and EP- $1 \alpha$ along with diethyl pyrocarbonate, and the polymerase chain reaction was conducted by using a PCR machine (NO5331 45348; Eppendorf, Germany). The primer sequences used in this PCR reaction were as follows:
For leptin: F:5'-AGT GGG AAT GAG AAA TCA CTT AGC-3', R:5'-GTG TAT TGC TTT TCA AGT GTC-3'. For adiponectin: F:5'-ACC TAC GAC CAG TAT CAG GAA AAG-3', R:5'- ACT AAG CTG AAA GTG TGT CGA CTG-3'. For TNF- $\alpha$ : F:5'-TCT TCT CAA AAT TCG AGT GAC AAG3', R:5'-GAG AAC CTG GGA GTA GAC AAG GTA-3'. For elongation factor- $1 \alpha$ (EF-1 $\alpha)$ : F:5'-CTC AGG TGA TTA TCC TGA ACC ATC-3', R:5'-AAC AGT TCT GAG ACC GTT CTT CCA-3').

Each primer's PCR cycle and annealing temperature was as follows:

Leptin: 212 bp, 30 cycles, $65^{\circ} \mathrm{C}$.

Adiponectin: 248 bp, 30 cycles, $59^{\circ} \mathrm{C}$.

TNF- $\alpha: 180$ bp, 30 cycles, $59^{\circ} \mathrm{C}$.

EF-1 $\alpha$ : 180 bp, 30 cycles, $58^{\circ} \mathrm{C}$.

The gene expression level of each protein was estimated by $1.5 \%$ agarose gel electrophoresis of the PCR products obtained by the above method. The level of gene expression in NOR was made the reference, and the gene expression level of each group was converted based on the reference value.

\section{Statistical Analysis}

Mean and standard error (SE) were calculated for statistical analysis. Student's t-test was performed to compare the mean of the experimental group and that of the control group, and the significance level (type I error) was set to 0.05 .

\section{RESULTS}

\section{Body-Weight Measurement}

At the beginning of this study, all the groups (NOR, CON, PFA, and PFB) had similar body weight. However, at the end of the study, the body weight of CON increased $15 \%$ compared to that of NOR, whereas that of PFA and PFB decreased $8 \%$ compared to that of NOR (Fig. 1).

\section{Weight Measurement of Fat in Liver and Epididymis}

\section{Liver}

After 8 weeks of feeding Fructus Pyri Pyrifoliae extract fermented by lactic-acid bacteria to the rats, there was no significant different in liver weight between PFA, PFB, and CON, but the mean weight of PFA $(11.74 \pm 1.05 \mathrm{~g})$ and that of PFB $(11.89 \pm 1.64 \mathrm{~g})$ decreased from that of CON $(13.21 \pm 1.19 \mathrm{~g})$ (Fig. 2).

\section{Epididymis fat}

After 8 weeks of feeding Fructus Pyri Pyrifoliae extract fermented by lactic-acid bacteria to the rats, there was a significant difference in the weight of epididymis fat between CON (3.08 $\pm 0.93 \mathrm{~g})$ and NOR (6.44 $\pm 1.02 \mathrm{~g})$, showing twice as much weight in NOR than in $\mathrm{CON}(\mathrm{p}<0.01)$. The weight 


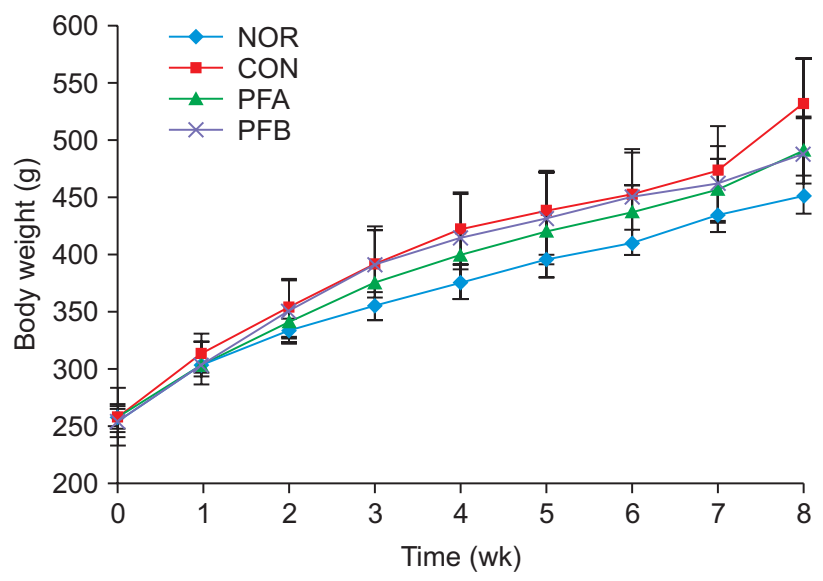

Fig. 1. The changes of body weight during 8 weeks. NOR, normal diet group administered water; CON, $60 \%$ high-fat diet (HFD) diet group administered water; PFA, $60 \%$ HFD diet group administered $1.7 \mathrm{~mL} / \mathrm{kg} /$ day Fructus Pyri Pyrifoliae fermented extract with lactic acid bacteria; PFB, $60 \%$ HFD diet group administered $5 \mathrm{~mL} / \mathrm{kg} /$ day Fructus Pyri Pyrifoliae fermented extract with lactic acid bacteria. All values are presented as mean \pm standard error $(n=6)$.

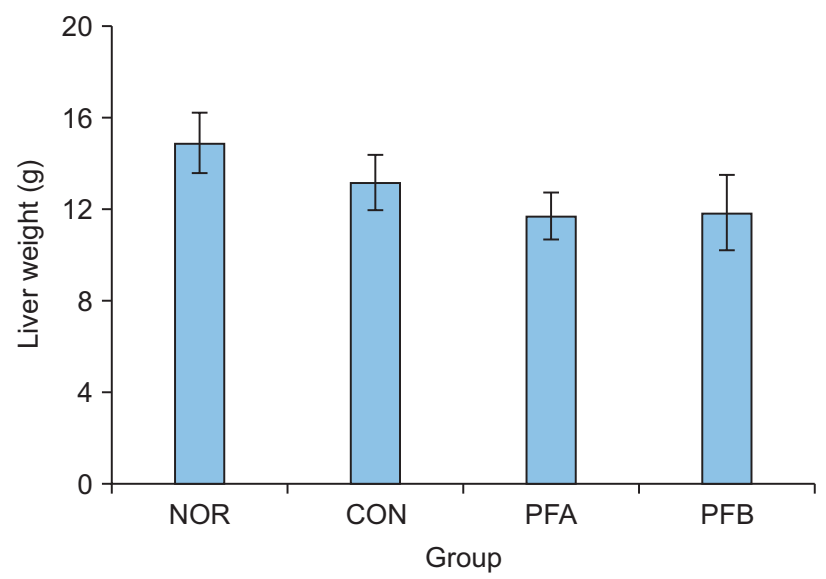

Fig. 2. The comparison of liver weight. NOR, normal diet group administered water; CON, $60 \%$ high-fat diet (HFD) diet group administered water; PFA, 60\% HFD diet group administered $1.7 \mathrm{~mL} / \mathrm{kg} /$ day Fructus Pyri Pyrifoliae fermented extract with lactic acid bacteria; PFB, $60 \%$ HFD diet group administered $5 \mathrm{~mL} / \mathrm{kg} /$ day Fructus Pyri Pyrifoliae fermented extract with lactic acid bacteria. All values are presented as mean \pm standard error $(n=6)$.

of epididymis fat in PFA $(4.90 \pm 0.55 \mathrm{~g})$ and PFB $(4.79 \pm 0.77$ g) were statistically significantly reduced by $25 \%$ compared to that of $\operatorname{CON}(\mathrm{p}<0.05$; Fig. 3$)$.

\section{Blood-cell analysis}

After 8 weeks of feeding Fructus Pyri Pyrifoliae extract fermented by lactic-acid bacteria to the rats, a higher WBC count was observed in CON $(5.87 \pm 0.55 \mathrm{~K} / \mu \mathrm{L})$ than in NOR $(5.16 \pm 0.60 \mathrm{~K} / \mu \mathrm{L})$, whereas $\mathrm{WBC}$ count decreased in both PFA $(5.22 \pm 0.63 \mathrm{~K} / \mu \mathrm{L})$ and PFB $(5.30 \pm 1.81 \mathrm{~K} / \mu \mathrm{L})$ compared

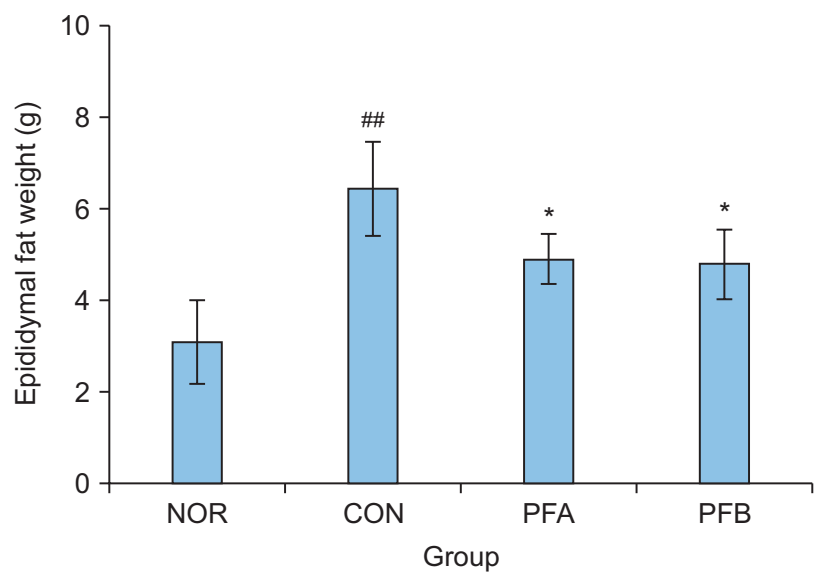

Fig. 3. The comparison of epididymal fat weight. NOR, normal diet group administered water; CON, $60 \%$ high-fat diet (HFD) diet group administered water; PFA, 60\% HFD diet group administered $1.7 \mathrm{~mL} / \mathrm{kg} /$ day Fructus Pyri Pyrifoliae fermented extract with lactic acid bacteria; PFB, $60 \%$ HFD diet group administered $5 \mathrm{~mL} / \mathrm{kg}$ /day Fructus Pyri Pyrifoliae fermented extract with lactic acid bacteria. All values are presented as mean \pm standard error $(n=6) .{ }^{* *} \mathrm{p}<0.01$ vs NOR; ${ }^{*} \mathrm{p}<0.05$ vs CON.

Table 1. The comparison of WBC, RBC, Hb, HCT, PLT

\begin{tabular}{|c|c|c|c|c|}
\hline & NOR & CON & PFA & PFB \\
\hline $\begin{array}{l}\text { WBC } \\
(\mathrm{K} / \mu \mathrm{L})\end{array}$ & $5.16 \pm 2.05$ & $5.87 \pm 0.60$ & $5.22 \pm 0.71$ & $5.30 \pm 1.81$ \\
\hline $\begin{array}{l}\mathrm{RBC} \\
(\mathrm{M} / \mu \mathrm{L})\end{array}$ & $9.24 \pm 0.35$ & $9.32 \pm 0.61$ & $9.38 \pm 0.40$ & $9.12 \pm 0.29$ \\
\hline $\begin{array}{l}\mathrm{Hb} \\
(\mathrm{g} / \mathrm{dL})\end{array}$ & $15.94 \pm 0.79$ & $16.44 \pm 1.05$ & $16.18 \pm 0.78$ & $16.08 \pm 0.81$ \\
\hline $\begin{array}{r}\mathrm{HCT} \\
(\%)\end{array}$ & $55.78 \pm 3.01$ & $56.46 \pm 2.49$ & $56.16 \pm 2.17$ & $55.04 \pm 1.48$ \\
\hline $\begin{array}{l}\text { PLT } \\
(\mathrm{K} / \mu \mathrm{L})\end{array}$ & $871.60 \pm 58.31$ & $866.00 \pm 131.35$ & $909.20 \pm 129.99$ & $872.80 \pm 131.40$ \\
\hline
\end{tabular}

Values are presented as mean \pm standard error $(\mathrm{n}=6)$.

NOR, normal diet group administered water; CON, $60 \%$ HFD diet group administered water; PFA, 60\% HFD diet group administered $1.7 \mathrm{~mL} / \mathrm{kg} /$ day Fructus Pyri Pyrifoliae fermented extract with lactic acid bacteria; PFB, $60 \%$ HFD diet group administered $5 \mathrm{~mL} / \mathrm{kg} /$ day Fructus Pyri Pyrifoliae fermented extract with lactic acid bacteria. WBC, white blood cell; RBC, red blood cell; Hb, hemoglobin; HCT, hematocrit; PLT, platelet.

to CON. For RBC count, a higher RBC count per $1 \mu \mathrm{L}$ was measured in CON $(9.32 \pm 0.61 \mathrm{M} / \mu \mathrm{L})$ and PFA $(9.38 \pm 0.40$ $\mathrm{M} / \mu \mathrm{L})$ than in NOR $(9.24 \pm 0.35 \mathrm{M} / \mu \mathrm{L})$, but PFB $(9.12 \pm 0.29$ $\mathrm{M} / \mu \mathrm{L}$ ) had a lower RBC than CON. For hemoglobin level, CON $(16.44 \pm 1.05 \mathrm{~g} / \mathrm{dL})$ tended to have a higher level than NOR $(15.94 \pm 0.79 \mathrm{~g} / \mathrm{dL})$, and PFA $(16.18 \pm 0.78 \mathrm{~g} / \mathrm{dL})$ and PFB $(16.08 \pm 0.81 \mathrm{~g} / \mathrm{dL})$ tended to have a lower level than NOR. The increased RBC volume was estimated in CON $(56.46 \% \pm 2.49 \%)$ compared to NOR $(55.78 \% \pm 3.01 \%)$, but the RBC volume of PFA $(56.16 \% \pm 2.17 \%)$ and PFB $(55.04 \% \pm 1.48 \%)$ didn't exceed that of CON. The platelet 


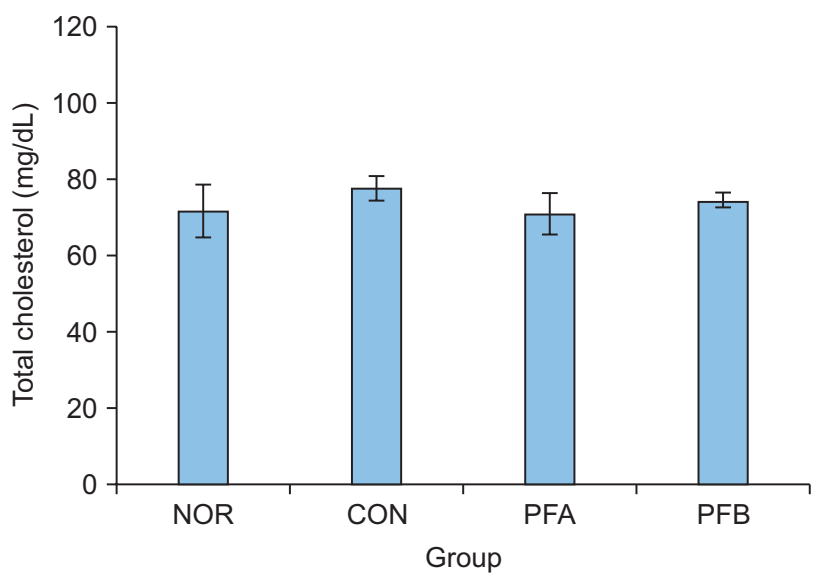

Fig. 4. The comparison of total cholesterol. NOR, normal diet group administered water; CON, $60 \%$ high-fat diet (HFD) diet group administered water; PFA, 60\% HFD diet group administered $1.7 \mathrm{~mL} / \mathrm{kg} /$ day Fructus Pyri Pyrifoliae fermented extract with lactic acid bacteria; PFB, $60 \%$ HFD diet group administered $5 \mathrm{~mL} / \mathrm{kg}$ /day Fructus Pyri Pyrifoliae fermented extract with lactic acid bacteria. All values are presented as mean \pm standard error $(\mathrm{n}=6)$.

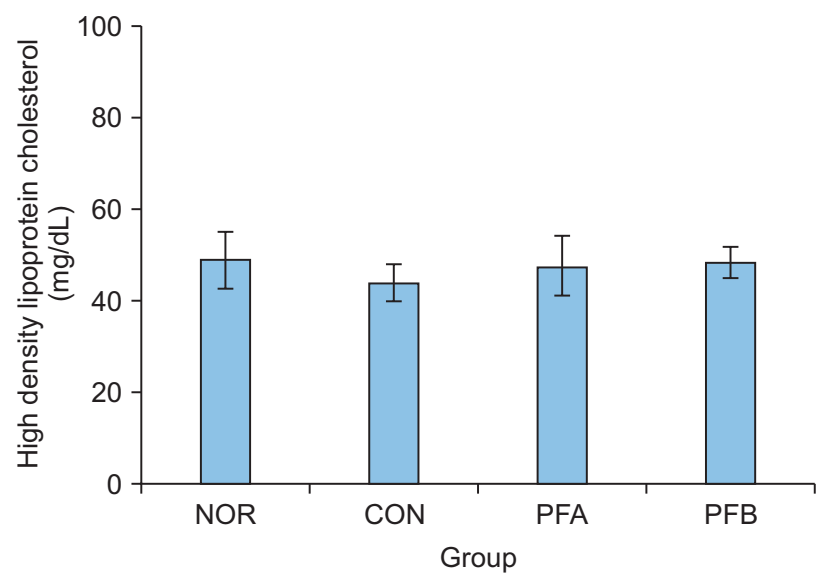

Fig. 5. The comparison of high density lipoprotein cholesterol. NOR, normal diet group administered water; CON, $60 \%$ high-fat diet (HFD) diet group administered water; PFA, 60\% HFD diet group administered $1.7 \mathrm{~mL} / \mathrm{kg} /$ day Fructus Pyri Pyrifoliae fermented extract with lactic acid bacteria; PFB, $60 \%$ HFD diet group administered $5 \mathrm{~mL} / \mathrm{kg} /$ day Fructus Pyri Pyrifoliae fermented extract with lactic acid bacteria. All values are presented as mean \pm standard error $(n=6)$.

analysis indicated that $\mathrm{CON}(866.00 \pm 131.35 \mathrm{~K} / \mu \mathrm{L})$ had a higher platelet level than NOR $(871.60 \pm 58.31 \mathrm{~K} / \mu \mathrm{L})$, and both PFA $(909.20 \pm 129.99 \mathrm{~K} / \mu \mathrm{L})$ and PFB $(872.80 \pm 131.40 \mathrm{~K} /$ $\mu \mathrm{L}$ ) had a higher platelet level than CON (Table 1).

\section{Serum lipid levels analysis}

Total cholesterol: After 8 weeks of feeding Fructus Pyri Pyrifoliae extract fermented by lactic-acid bacteria to the rats, we found a slightly higher level of total cholesterol in CON $(77.80 \pm 3.11 \mathrm{mg} / \mathrm{dL})$ than in NOR $(71.60 \pm 6.99 \mathrm{mg} / \mathrm{dL})$,

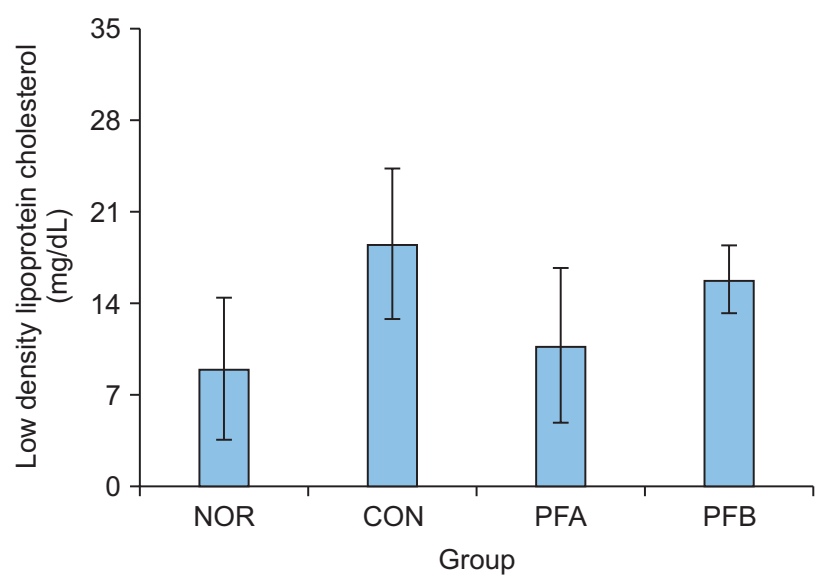

Fig. 6. The comparison of low density lipoprotein cholesterol. NOR, normal diet group administered water; CON, $60 \%$ high-fat diet (HFD) diet group administered water; PFA, 60\% HFD diet group administered $1.7 \mathrm{~mL} / \mathrm{kg} /$ day Fructus Pyri Pyrifoliae fermented extract with lactic acid bacteria; PFB, $60 \%$ HFD diet group administered $5 \mathrm{~mL} / \mathrm{kg} /$ day Fructus Pyri Pyrifoliae fermented extract with lactic acid bacteria. All values are presented as mean \pm standard error $(n=6)$.

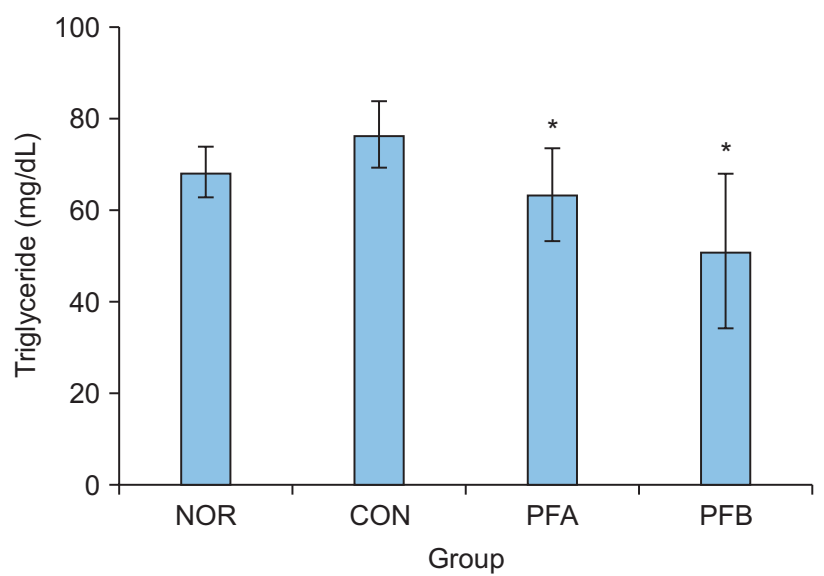

Fig. 7. The comparison of triglyceride. NOR, normal diet group administered water; CON, $60 \%$ high-fat diet (HFD) diet group administered water; PFA, 60\% HFD diet group administered $1.7 \mathrm{~mL} / \mathrm{kg} /$ day Fructus Pyri Pyrifoliae fermented extract with lactic acid bacteria; PFB, 60\% HFD diet group administered $5 \mathrm{~mL} / \mathrm{kg} /$ day Fructus Pyri Pyrifoliae fermented extract with lactic acid bacteria. All values are presented as mean \pm standard error $(n=6)$. Significant difference were compared with control group at ${ }^{*} \mathrm{p}<0.05$.

but PFA $(71.00 \pm 5.48 \mathrm{mg} / \mathrm{dL})$ and PFB $(74.40 \pm 1.95 \mathrm{mg} / \mathrm{dL})$ showed a lower total cholesterol level than in CON (Fig. 4). HDL cholesterol: After 8 weeks of feeding Fructus Pyri Pyrifoliae extract fermented by lactic-acid bacteria to the rats, the HDL-C level was a bit reduced in CON $(38.60 \pm 7.21 \mathrm{mg} / \mathrm{dL})$ compared to NOR $(50.00 \pm 10.05 \mathrm{mg} / \mathrm{dL})$, but was elevated in PFA $(47.80 \pm 5.45 \mathrm{mg} / \mathrm{dL})$ and PFB $(47.00 \pm 9.07 \mathrm{mg} / \mathrm{dL})$ compared to CON (Fig. 5). 
LDL cholesterol: Low density lipoprotein (LDL) measurement results, after feeding the extract fermented by lacticacid bacteria to the rats for 8 weeks, indicated that the LDL level of CON $(18.52 \pm 5.77 \mathrm{mg} / \mathrm{dL})$ was higher than that of NOR $(8.96 \pm 5.45 \mathrm{mg} / \mathrm{dL})$, whereas the LDL levels of PFA
$(10.72 \pm 5.90 \mathrm{mg} / \mathrm{dL})$ and $\mathrm{PFB}(15.80 \pm 2.58 \mathrm{mg} / \mathrm{dL})$ were lower than that of CON (Fig. 6).

Triglycerides: Triglyceride measurement results, after feeding the extract fermented by lactic-acid bacteria to the rats for 8 weeks, indicated that the triglyceride level of CON $(76.40 \pm 7.23$
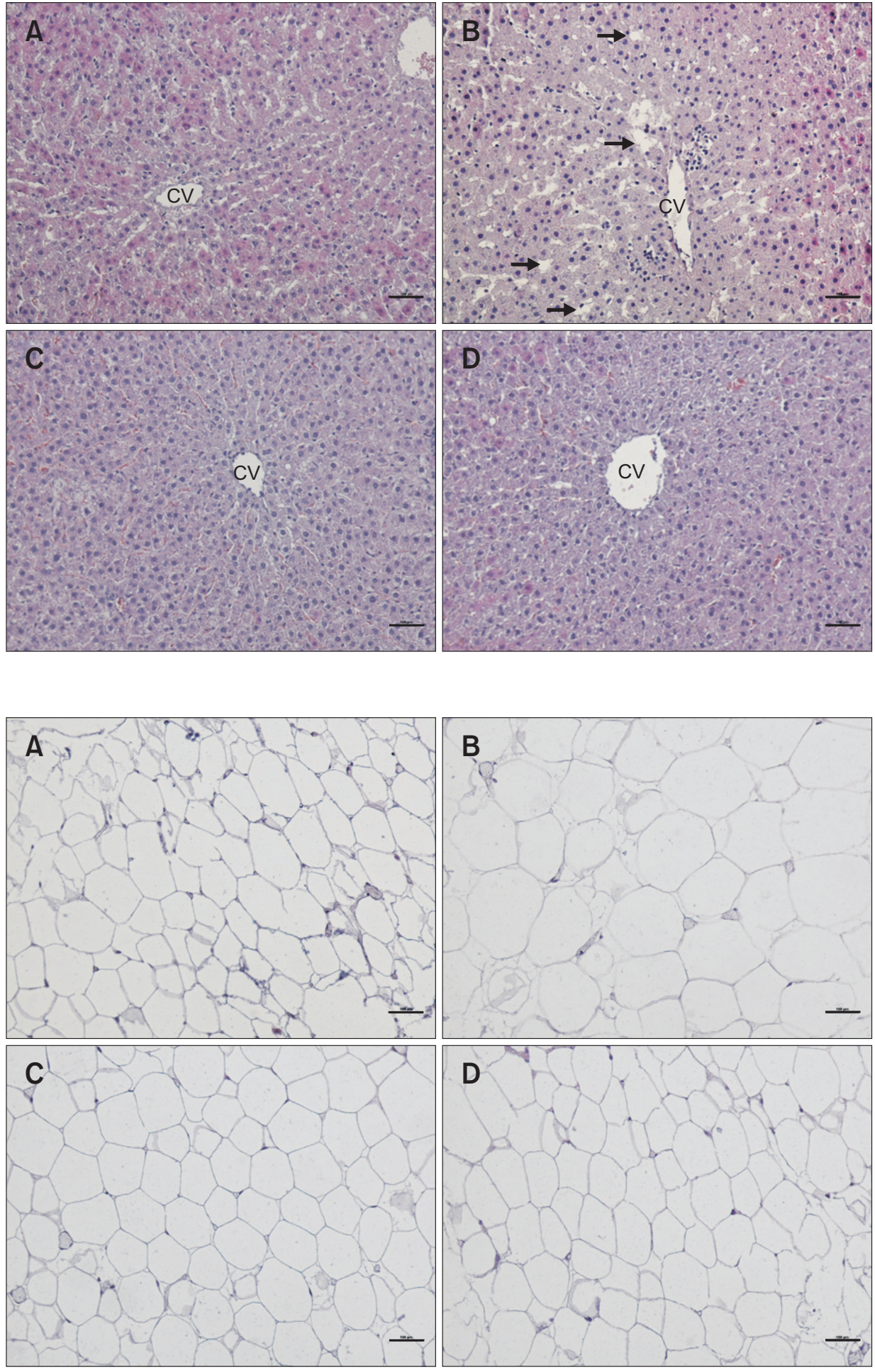

Fig. 8. Light micrographs of liver tissue in rats. (A) Normal diet group administered water. (B) $60 \%$ high-fat diet (HFD) diet group administered water. (C) $60 \% \mathrm{HFD}$ diet group administered $1.7 \mathrm{~mL} / \mathrm{kg} /$ day Fructus Pyri Pyrifoliae fermented extract with lactic acid bacteria. (D) $60 \%$ HFD diet group administered $5 \mathrm{~mL} / \mathrm{kg} /$ day Fructus Pyri Pyrifoliae fermented extract with lactic acid bacteria. CV, central vein; arrows, lipid droplet. (A-D) H\&E stain, $\times 200$. Scale bars $=100 \mu \mathrm{m}$.

Fig. 9. Light micrographs of epididymal fat tissue in rats. (A) Normal diet group administered water. (B) $60 \%$ high-fat diet (HFD) diet group administered water. (C) $60 \%$ HFD diet group administered 1.7 $\mathrm{mL} / \mathrm{kg} /$ day Fructus Pyri Pyrifoliae fermented extract with lactic acid bacteria. (D) $60 \%$ HFD diet group administered 5 $\mathrm{mL} / \mathrm{kg} /$ day Fructus Pyri Pyrifoliae fermented extract with lactic acid bacteria. (A-D) H\&E stain, $\times 200$. Scale bars $=100$ $\mu \mathrm{m}$. 
$\mathrm{mg} / \mathrm{dL})$ was higher than that of NOR $(68.20 \pm 5.54 \mathrm{mg} / \mathrm{dL})$, but the triglyceride levels of PFA $(63.40 \pm 10.11 \mathrm{mg} / \mathrm{dL})$ and PFB $(51.00 \pm 17.00 \mathrm{mg} / \mathrm{dL})$ were statistically significantly lower than that of CON (Fig. 7).

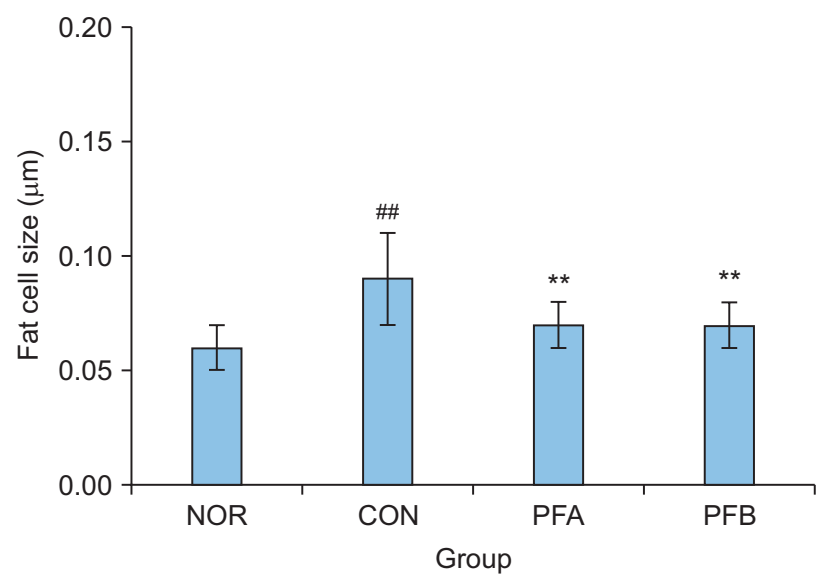

Fig. 10. Epididymal fat cell size of rats. NOR, normal diet group administered water; CON, $60 \%$ high-fat diet (HFD) diet group administered water; PFA, 60\% HFD diet group administered $1.7 \mathrm{~mL} / \mathrm{kg} /$ day Fructus Pyri Pyrifoliae fermented extract with lactic acid bacteria; PFB, 60\% HFD diet group administered $5 \mathrm{~mL} / \mathrm{kg} /$ day Fructus Pyri Pyrifoliae fermented extract with lactic acid bacteria. All values are presented as mean \pm standard error $(\mathrm{n}=6) .{ }^{* *} \mathrm{p}<0.01$ vs NOR; ** $\mathrm{p}<0.01$ vs $\operatorname{CON}(\times 100)$.

\section{Light microscope observation of lipids in liver and epididymis}

Liver: Following feeding the extract fermented by lactic-acid bacteria to the animals for 8 weeks, round or oval nucleus and less distributed lipid droplets were observed in NOR (Fig. 8A). In $\mathrm{CON}$, numerous lipid droplets were evenly distributed, and cytoplasm in CON was less eosinophilic than in NOR (Fig. 8B). In PFA and PFB, lipid droplets were less likely to be distributed than in $\mathrm{CON}$, but more eosinophilic was observed than in NOR (Fig. 8C and D).

Fat in Epididymis: Compared to NOR (Fig. 9A), a remarkably increased size of adipose cells was confirmed in CON (Fig. 9B). In PFA (Fig. 9C) and PFB (Fig. 9D), adipose cells were somewhat larger than in NOR, but were smaller than in CON.

\section{Adipose cell-size measurement in epididymis fat}

Adipose cells in CON $(0.09 \pm 0.02 \mu \mathrm{m})$ were $34 \%$ bigger than that in NOR $(0.06 \pm 0.01 \mu \mathrm{m})$. There was a significant reduction of adipose cell size by $23 \%$ in both PFA $(0.07 \pm 0.01 \mu \mathrm{m})$ and PFB $(0.07 \pm 0.01 \mu \mathrm{m})$ compared to $\mathrm{CON}(\mathrm{p}<0.01$; Fig. 10).

\section{Electron microscope observation of hepatocytes}

The electron microscopic observation of normal rats showed the hepatocytes are delimited by a well-defined cytoplasmic membrane, a number of rounded or elongated mitochon-
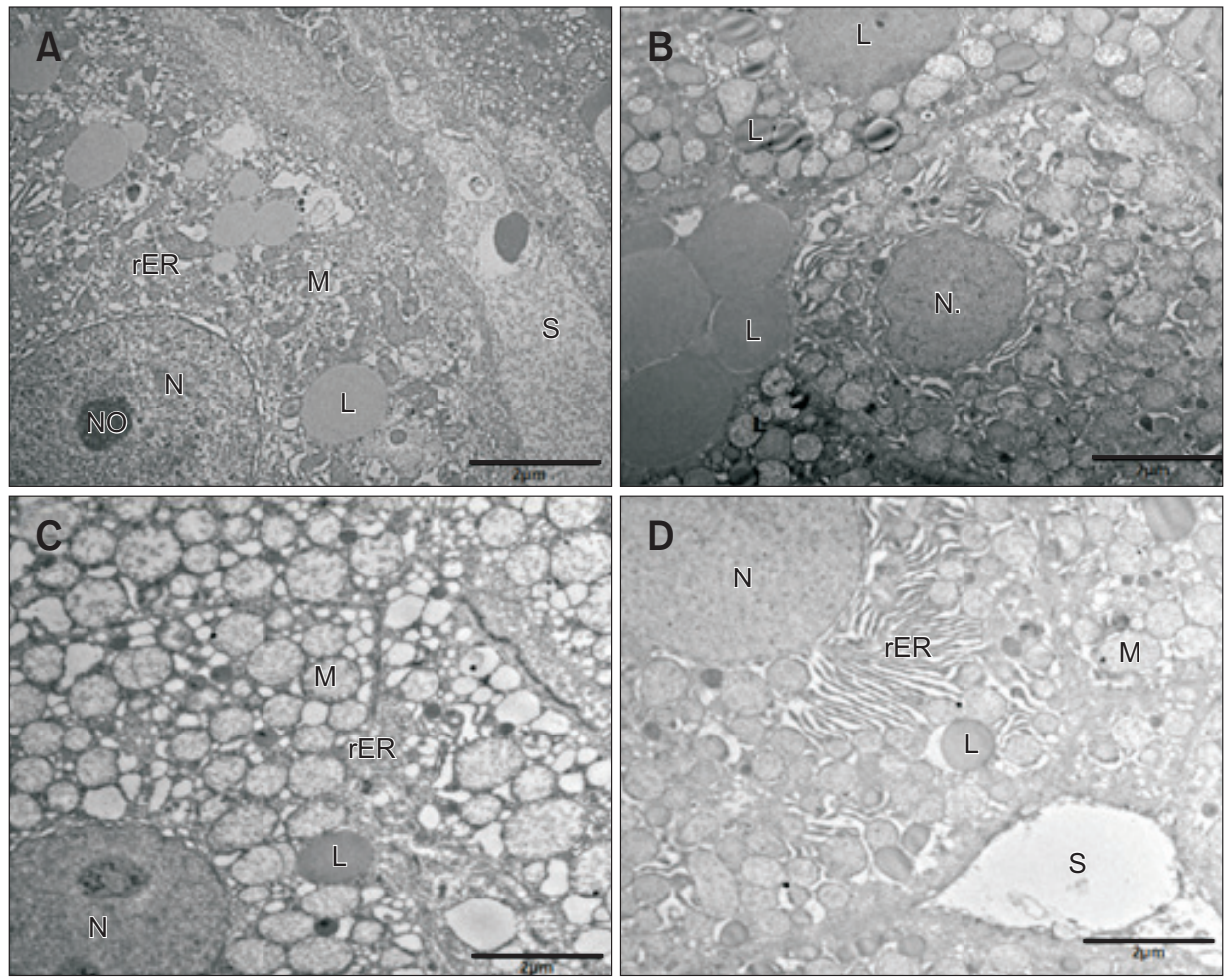

Fig. 11. Electron micrograph of hepatocytes of rats. (A) Group A, normal diet group administered water. (B) Group B, $60 \%$ high-fat diet (HFD) diet group administered water. (C) Group C, 60\% HFD diet group administered $1.7 \mathrm{~mL} / \mathrm{kg} /$ day Fructus Pyri Pyrifoliae fermented extract with lactic acid bacteria. (D) Group D, $60 \%$ HFD diet group administered $5 \mathrm{~mL} /$ $\mathrm{kg}$ /day Fructus Pyri Pyrifoliae fermented extract with lactic acid bacteria. A number of lipid droplets are observed in the group B compared with group A. The lipid droplets are decreased in the group $C$ and D compared with group B. NO, nucleolus; rER, rough endoplasmic reticulum; $\mathrm{N}$, nucleus; $\mathrm{M}$, mitochondria; L, lipid droplet; S, sinusoid. (A-D) $\times 5,000$. Scale bars $=2$ $\mu \mathrm{m}$. 


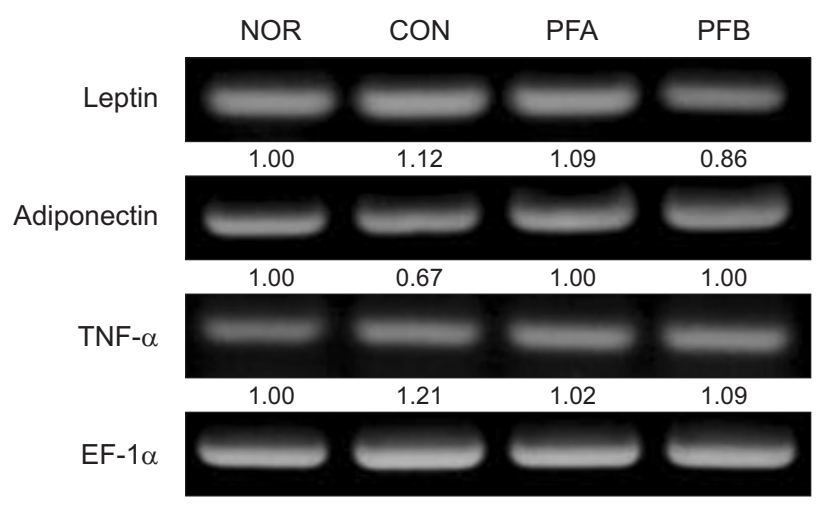

Fig. 12. The gene expression of leptin, adiponectin, tumor necrosis factor- $\alpha$ (TNF- $\alpha)$ of hepatocyte in rats. NOR, normal diet group administered water; CON, $60 \%$ high-fat diet (HFD) diet group administered water; PFA, 60\% HFD diet group administered $1.7 \mathrm{~mL} / \mathrm{kg} /$ day Fructus Pyri Pyrifoliae fermented extract with lactic acid bacteria; PFB, 60\% HFD diet group administered $5 \mathrm{~mL} / \mathrm{kg} /$ day Fructus Pyri Pyrifoliae fermented extract with lactic acid bacteria.

dria, normal rough endoplasmic reticulum and nucleus with nucleolus (Fig. 11A). In the CON, the most striking features are the appearance of hepatocytes with abnormal nuclei contained a lot of heterochromatin, and a number of swollen mitochondria and lipid droplets of different sizes are observed in the hepatocytes and sinusoidal cells (Fig. 11B). In the PFA, a number of swollen mitochondria are observed, but lipid droplets are scarcely observed (Fig. 11C). In the PFB, small lipid droplets are hardly observed, mitochondria are swollen, but rough endoplasmic reticulum are developed (Fig. 11D).

\section{Gene expression of leptin, adiponectin, and TNF- $\alpha$ in liver cells}

When the gene-expression level of NOR after 8 weeks was considered as reference (set to 1), the leptin gene-expression level of CON (1.12) relatively increased, but that of PFA (1.09) and PFB (0.86) decreased relative to that of CON (Fig. 12). For adiponectin gene expression compared to that of NOR (set to 1) after 8 weeks, the level of gene expression in CON was calculated as 0.67 , indicating relatively decreased gene expression, whereas PFA (1.00) and PFB (1.00) showed the same level of adiponectin gene expression as NOR and were elevated compared to CON.

For TNF- $\alpha$ gene expression compared to that of NOR (set to 1) after 8 weeks, the level of gene expression in CON was calculated as 1.21 indicating relatively increased gene expression, whereas PFA (1.02) and PFB (1.09) showed decreased gene expression of TNF- $\alpha$ compared to that of CON (Fig. 12).

\section{DISCUSSION}

Obesity occurs when adipose cells are actively differentiated and triglyceride is excessively accumulated because of excess energy intake (Bae et al., 2014). Obesity can increase the risk of lifestyle disease such as hypertension, arteriosclerosis, cardiovascular disease, and diabetes. The obesity rate is increasing remarkably in the world, including South Korea, and there are many studies on how to reduce obesity in the population (Jequier, 2002; Wang \& Cho, 2011).

Obesity refers to excess accumulation of triglycerides in our body due to imbalances between energy intake and expenditure. Obesity is the main risk factor for coronary artery disease by generating adipocytes (hyperplasia) as well as increasing their cell size (hypertrophy) (Wang \& Cho, 2011), and a major cause of diabetes, hypertension, hyperlipidemia, and inflammatory and metabolic disorders (Rhyu et al., 2014). The World Health Organization (WHO) requires intensive, worldwide management of obesity because of its seriousness (Wang \& Cho, 2011).

There have been many different anti-obesity drugs. However, most of them have adverse effects, such as headache, insomnia, nervousness, tachycardia, and gastrointestinal diseases. For this reason, the anti-obesity activity of natural products as well as food are actively studied (Song et al., 2013). Park et al. (2010) examined the effect of green tea extract for regulating epididymal fat accumulation in mice, and confirmed its effectiveness for decreasing body-fat accumulation and fat metabolism. Lee et al. (2013) studied the anti-obesity effect of soybean curd residue fermented by Monascus pilosus, and reported that it reduced the fat proportion in the liver and prevented generation of reactive oxygen species, thus showing anti-obesity activity. In addition, Lee et al. (2014) investigated the anti-obesity effects of Lentinus edodes on obesity induced in mice by a HFD, and concluded that Lentinus edodes is effective for body-weight loss, body-fat reduction and lowering serum lipid level.

Most of the pears produced in South Korea are Asian Pears, harvested in Naju, Jeollanam-do, South Korea. Pears contain high sugar and water, and there are plentiful antioxidative polyphenol substances especially on pear skin, such as arbutin, epicatechin, coumaric acid, caffeic acid, catechin, and chlorogenic acid (Rhyu et al., 2014). The edible part of pears contains sugar, largely in the form of fructose rather than glucose, and has less organic acid, resulting in less sour taste than in an apple. Although most pears are eaten as a fruit itself, pears can be used to cook tartare or Bulgogi, because of the enzymes in pears that have a tenderizing effect on meat, or to make canned food or juice. Min et al. (2013) reported that pears have anti-hypertension, anti-diabetes, anti-obesity, detoxification, immune-boosting, and serum lipid lowering effects. Furthermore, they also reported that pears can excrete and eliminate a carcinogen, polycyclic aromatic hydrocarbons (Min et al., 2013). You (2015) investigated the anti-obesity effect of pear pomace, and found that it fights obesity by preventing the generation of adipocytes and reducing both body 
weight and body fat in animal.

So far, pears have been consumed as an edible fruit or as a juice without pear fiber. But there has been little research on various processing methods and other ways to use pears. Among the preceding studies, Pucel (2014) reported that fermented pears or fruits with lactic-acid bacteria become a functional substance. Also, Chandrakant et al. (2012) found that pear juice fermented by lactic-acid bacteria can ameliorate type II diabetes because it reinforces bioactivity in in vitro enzyme analysis.

Fermenting by lactic-acid bacteria has been widely applied to many ingredients and studied by researchers. Although the anti-obesity effect of pears has been known, there was no preceding study using lactic-acid bacteria fermentation. Hence, we felt the need to study lactic-acid bacteria fermentation of Fructus Pyri Pyrifoliae.

Leuconostoc genus, the heterofermentative lactic-acid bacteria used in this study, mainly exist in sugar solutions, vegetables, fruits, and milk, and ferment glucose to lactate, carbon dioxide, and ethanol. L. mesenteroides is the one of the most popular bacteria in this genus, playing an important role in Cheongju brewing, and its optimal growth temperature is relatively low, $20^{\circ} \mathrm{C}$ to $22^{\circ} \mathrm{C}$. Lactic-acid bacteria can directly affect intestinal flora in the human body. Also, lactic-acid bacteria can affect other microorganisms by regulating immunological factors as well as nutrition and metabolism, intestinal permeability, and the production of bioactive substances (Delzenne et al., 2011; de Vrese \& Schrezenmeir, 2008; Gerritsen et al., 2011). Kim et al. (2008) reported that soybean milk fermented by Leuconostoc plantarum and Leuconostoc citreum reduced LDL level in blood, inhibited the differentiation of 3T3-L1 into adipocyte. Lee et al. (2013) revealed that soybean milk fermented by Leuconostoc paracasei subsp. paracasei NTU 101(NTU101) has anti-obesity activity in rats fed a HFD.

Therefore, this study investigated the effect of improving the serum lipid profile and lowering body fat in obesity-induced rats fed a HFD by using L. mesenteroides subsp. mesenteroids GAVOL-01 in pear pulps, a by-product of pear juice extraction.

The results indicated that feeding Fructus Pyri Pyrifoliae extract fermented by lactic-acid bacteria during the 8 weeks of this study helped reduce the body weight of the laboratory rats. Also, the fat weights of both liver and epididymis were more reduced in experimental groups fed the extract fermented by lactic-acid bacteria for 8 weeks than in the control group, and especially the epididymial fat weight was statistically significantly different. From this result, we can conclude that Fructus Pyri Pyrifoliae extract fermented by lactic-acid bacteria can help reduce body fat. You (2015) reported that groups fed pear pomace extract tended to have lower epididymal fat, and Um et al. (2013) insisted that a HFD can cause hypertension, hyperlipidemia, and various metabolic disor- ders by accumulating fat around organs and under the skin. Along with hypertriglyceridemia, hyperlipidemia induced by obesity has been known as a main cause of lifestyle diseases (Yoon et al., 2014). Park et al. (2010) maintained that obesityinduced abnormal fat metabolism can cause dyslipidemia, showing an elevated serum level of triglyceride, total cholesterol, and glucose. Taken all together, the effect of lowering serum lipid, observed in this study, by Fructus Pyri Pyrifoliae extract fermented by lactic-acid bacteria may result from the reduction of serum total cholesterol level and triglyceride level.

Since adipocyte hypertrophy in tissues is due to deposits of triglyceride in adipose cells, measuring the size of adipocytes is a reasonable way to study obesity. Kim et al. (2007) showed that if more cells were observed in the same area, that increase would result from cell-size reduction, which indicates inhibiting the hypertrophy of adipose cells. In this study, we observed statistically meaningful adipose cell-size reduction in epididymal fat among the experimental groups compared to the control group. So the intervention is judged to have effective anti-obesity activity.

In the ultrastructural investigation, rats treated with extracts with large number of mitochondria, normal nucleus and well developed rough endoplasmic reticulum (rER), one of organelle in the cell, indicating regeneration of liver, extensive rER reflected the cell activity to make high amount of proteins (Mashael et al., 2017).

Leptin, a hormone secreted by adipose tissue to maintain body-fat level, is known to be involved in controlling appetite by stimulating the hypothalamic appestat as needed (Kang et al., 2004). It is known that patients who have diabetes, obesity, or coronary artery disease tend to have less adiponectin, which is produced in adipose tissue, than a normal group has. Also, adiponectin is related to glucose metabolism as well as to insulin resistance and plays an important role in development of atherosclerosis (Park \& Yoo, 2004). As a pro-inflammatory cytokine, TNF- $\alpha$ is related to metabolic syndromes. Hypertrophy of adipocytes can increase the number of macrophages and, as a result, various inflammatory signals including TNF- $\alpha$ that can induce insulin resistance are released (Choi \& Kim, 2015). In this research, increased leptin expression in the liver was observed among the experimental groups fed the fermented extract than in the control group, whereas expression of adiponectin and TNF- $\alpha$ was reduced in the experimental groups compared to the control. Thus, Fructus Pyri Pyrifoliae extract fermented by lactic-acid bacteria seems to inhibit adipose cell function and differentiation and regulate lipid metabolism for obesity.

In conclusion, body-weight loss, reducing body fat accumulation, lowering serum lipid level, suppressing production and hypertrophy of adipocytes, and inhibiting gene expression of adipocytokines in adipose tissue were observed in the obese 
laboratory rats fed Fructus Pyri Pyrifoliae extract fermented by lactic-acid bacteria, indicating that the fermented extract may have a remarkable anti-obesity effect.

\section{CONCLUSIONS}

This study investigated the anti-obesity effect of Fructus Pyri Pyrifoliae extract fermented by lactic-acid bacteria on rats fed a HFD. The study animals were divided into 4 groups and provided with different feeds and intervention for 8 weeks. Then, the rats were sacrificed to examine body weight, organ weight, blood cells, serum analysis, morphological change of adipose tissue in liver and epididymis, microstructure of liver cells, and gene expression level of leptin, adiponectin, and TNF- $\alpha$. The summary of results is as follows.

1. Compared to CON, PFA, and PFB fed Fructus Pyri Pyrifoliae extract fermented by lactic-acid bacteria, showed $8 \%$ body-weight loss, especially a $25 \%$ reduction in epididymal fat.

2. A lower level of total cholesterol, LDL cholesterol, and triglycerides in serum was observed in the groups provided Fructus Pyri Pyrifoliae extract fermented by lactic-acid bacteria than in in CON.
3. In PFA and PFB, less fat accumulation in liver and epididymis than in CON was observed using a light microscope. Furthermore, the adipocyte size of epididymis in PFA and PFB was significantly reduced by $23 \%$ compared to CON.

4. The observations through an electron microscope indicated that PFA and PFB had smaller lipid droplets than CON had.

5. Leptin expression was elevated in the experimental groups compared to $\mathrm{CON}$, whereas expression of adiponectin and TNF- $\alpha$ was reduced in the experimental groups compared to CON.

From the results of this study, when Fructus Pyri Pyrifoliae extract fermented by lactic-acid bacteria was provided, there was a statistically meaningful reduction in weight gain, increasing adipocyte, and gene expression that were induced by the HFD. Therefore, Fructus Pyri Pyrifoliae extract fermented by lactic-acid bacteria can be effective in preventing and treating obesity by reducing body weight as well as adipose cells.

\section{CONFLICT OF INTEREST}

No potential conflict of interest relevant to this article was reported.

\section{REFERENCES}

Bae I S, Kim H J, Chung K Y, Choi I H, and Kim S H (2014) Transcriptional regulation of microRNA-17 by PPARy in adipogenesis. J. Life Sci. 24, 323-328.

Chandrakant A, Marcia P, Duane G, and Kalidas S (2012) In vitro bioassay based screening of antihyperglycemia and antihypertensive activities of Lactobacillus acidophilus fermented pear juice. Innov. Food Sci. Emerg. Technol. 13, 221-230.

Choi E J and Kim E K (2015) Effects of difference exercise intensity on adipokine and adipose related genes expression in type 2 diabetic mice. Korean J. Sports Sci. 24, 1301-1310.

Delzenne N M, Neyrinck A M, Bäckhed F, and Cani P D (2011) Targeting gut microbiota in obesity: effects of prebiotics and probiotics. Nat. Rev. Endocrinol. 7, 639-646.

de Vrese M and Schrezenmeir J (2008) Probiotics, prebiotics and synbiotics. Food Biotechnol. 111, 1-66.

Gerritsen J, Smidt H, Rijkers G T, and de Vos W M (2011) Intestinal microbiota in human health and disease: the impact of probiotics. Genes Nutr. 6, 209-240.

Jequier E (2002) Pathways to obesity. Int. J. Obes. 26, 12-17.

Kang K J, Choi S S, Han H K, Kim K J, and Kwon S Y (2004) Effects of instant coffee on weight, plasma lipids, leptin, and fat cell size in rats fed on a high-fat diet. Korean J. Food Sci. Technol. 36, 478-483.

Kim H S and Ham J S (2003) Antioxidative ability of lactic-acid bacteria. Korean J. Food Sci. Anim. Resour. 23, 186-192.

Kim H S, Kim T W, Kim D J, Hwang H J, Lee H J, and Choe M (2007) Effects of natural plants supplementation on adipocyte size of the epi- didymal fat pads in rats. J. Korean Soc. Food Sci. Nutr. 36, 419-423.

Kim N H, Moon P D, Kim S J, Choi I Y, An H J, Myung N Y, and Kim H M (2008) Lipid profile lowering effect of Soypro fermented with lacticacid bacteria isolated from Kimchi in high-fat diet-induced obese rats. Biofactors 33, 49-60.

Kim Y M, Jeong H J, Chung H S, Seong J H, Kim H S, Kim D S, and Lee Y G (2016) Anti-oxidative activity of the Extracts from Houttuynia cordata Thunb. fermented by lactic-acid bacteria. J. Life Sci. 26, 468-474.

Lee B H, Lo Y H, and Pan T M (2013) Anti-obesity activity of Lactobacillus fermented soy milk products. J. Funct. Foods 5, 905-913.

Lee M R, Oh D S, Wee A J, Yun B S, Jang S A, and Sung C K (2014) Antiobesity effects of Lentinus edodes on obese mice induced by high fat diet. J. Korean Soc. Food Sci. Nutr. 43, 194-199.

Maria K and Athanasios A K (2016) Dairy and non-dairy probiotic beverages. Curr. Opin. Food Sci. 7, 58-63.

Mashael M B, Ali A S, Refaat A E, and Attalla F E (2017) Anti-obesity and anti-hepatosteatosis effects of dietary Zingiber officinale extract in male obese rats. Int. J. Pharmacol. 13, 620-627.

Min T S, Park M J, Moon J H, Kim W S, Lee S H, Cho Y D, and Park S H (2013) Bio-active substances and physiological activity of pears. J. Appl. Biol. Chem. 56, 83-87.

Park H K and Yoo Y H (2004) Relationship of adiponectin to obesity, type 2 diabetes and coronary artery disease. Soonchunhyang Med. Sci. 10, 319-325.

Park J S and Han I H (2015) Effect of extraction solvent on the physiological properties of Korean pear peel (Pyrus pyrifolia cv. Niitaka). Ko- 
rean J Food Sci. Technol. 47, 254-260.

Park P J, Kim C W, Cho S Y, Rha C S, Seo D B, and Lee S J (2010). Aqueous spray-dried green tea extract regulates body weight and epididymal fat accumulation in mice. Korean J. Food Sci. Technol. 4, 103108.

Pucel N W (2014) Improvement of functional bioactivity in pear:blackberry synergies with lactic acid fermentation for type 2 diabetes and hypertension management. Master's thesis, (University of Massachusetts Amherst, Amherst).

Rhyu J, Kim M S, You M K, Bang M A, and Kim H A (2014) Pear pomace water extract inhibits adipogenesis and apoptosis in 3T3-L1 adipocytes. Nutr. Res. Pract. 8, 33-39.

Song M Y, Bose S, and Kim H J (2013) Anti-obesity effects of fermented Samjung-hwan in high fat diet rats. J. Korean Med. Obes. Res. 13, 17-23.

Tsai T Y, Chu L H, Lee C L, and Pan T M (2009) Atherosclerosis-preventing activity of lactic-acid bacteria-fermented milk-soymilk supplemented with Momordica charantia. J. Agric. Food Chem. 57, 2065-2071.
Um M Y, Choi W H, Ahn J Y, and Ha T Y (2013) Effects of ethanol extract of Ulmus davidiana root on lipid metabolism in high-fat diet fed mice. Korean J. Food Nutr. 26, 8-14.

Wang S B and Cho Y C (2011) Body mass index and subsequent risk of hypertension, hyperglycemia and hypercholesterolemia in health checkup examinees. J. Korea Acad-Indust. Coop. Soc. 12, $2677-$ 2684.

Yang H S, Choi Y J, Oh H H, Moon J S, Jung H K, Kim K J, Choi B S, Lee J W, and Huh C K (2014) Antioxidative activity of mushroom water extracts fermented by lactic-acid bacteria. J. Korean Soc. Food Sci. Nutr. 43, 80-85.

Yoon Y S, Keum S O, Lee S W, Kim I H, Lee H I, and Song Y S (2014) Effects of Cheongshimyeonja-tang on body weight and serum lipid levels in high-fat diet induced obese mice. Herb. Formul. Sci. 22, 123139.

You J (2015) Anti-obesity effects of pear pomace extracts. Master's thesis, (Graduate School of Mokpo National University, Muan). 